\title{
Research on the Performance of Cooling Module with Fuel Cell Vehicle
}

\author{
He Chang ${ }^{*}, 1,2$ Xiumin $\mathrm{YU}^{2}$ and Jing Hua Lv ${ }^{1}$
}

${ }^{1}$ FAW CAR Co. Ltd. Chang Chun, China

${ }^{2}$ State Key Laboratory of Automotive Simulation and Control, Jilin University, Changchun, China

\begin{abstract}
Cooling-module simulation for the fuel cell car has been built according with CFD and KULI software. The simulation results are compared with the test data to verify the authenticity of the module. Based on 3D and 1D calculation of the module is done to analyze the effect on the performance of the cooling module for fuel cell car.
\end{abstract}

Keywords: Cooling module, fuel cell car, performance, simulation.

\section{INTRODUCTION}

Fuel cell operating temperature range is close to the ambient temperature so the cooling module of the fuel cell car faces difficutly in transfering heat to the surroundings. Therefore, it has a great influence on the performance of fuel cell car [1-3]. There are some aspects of cooling system design. The first is the lower operating temperature as compared to the standard operating temperature. The other is higher energy in the fuel cell cooling system than that in the conventional car. From the above, it is needed that when designing a cooling model its performance should accurately match the fuel cell car. The technology roadmap is shown in Fig. (1).
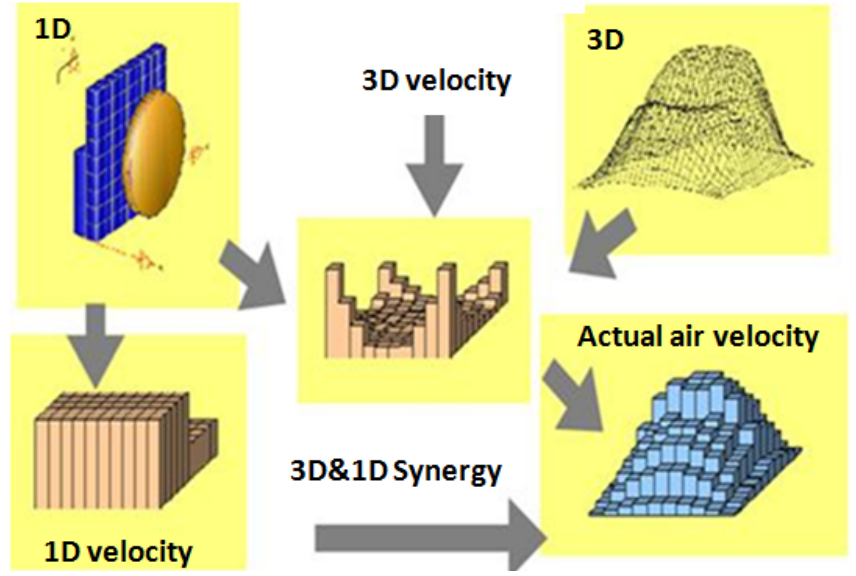

Fig. (1). The technology roadmap.

As we know, 3D results can reflect the actual flow field inside the cabin, but $1 \mathrm{D}$ result can not depict the complex flow field inside the cabin. In order to get correct and accurate calculation results, we have to find the CFD calculation and the 1D calculation of the velocity matrix. In this way we can accurately calculate the flow and heat transfer

*Address correspondence to this author at the FAW CAR Co. Ltd. Chang Chun, China; Tel: 0431-13944836786; Fax: 0431-81504449;

E-mail:n4n4china@126.com model of the fuel cell car, thus obtaining a result beneficial to design the cooling model of the fuel cell car [4-6].

\section{SIMULATION}

By the CFD instead of the wind tunnel test, we get air characteristic parameters, which will help in the synergy simulation [7-9] as shown in Fig. (2). The 3D simulation Parameter is shown in Table $\mathbf{1 .}$

Table 1. The 3D simulation parameter.

\begin{tabular}{|c|c|}
\hline \multicolumn{2}{|c|}{ CFD Input Date } \\
\hline \hline Air & $1.18145 \mathrm{~kg} / \mathrm{m} 3$ \\
\hline Air & $1.85508 \times 10^{-5} \mathrm{~Pa} \cdot \mathrm{s}$ \\
\hline Velocity inlet & $30-140 \mathrm{~km} / \mathrm{h}$ \\
\hline Pressure Outlet & $0.0 \mathrm{~Pa}$ \\
\hline Wall & Slip \\
\hline Fan rate & $3300 \mathrm{rpm}$ \\
\hline Grid & Trimmed/layer mesh \\
\hline Model & SST K-Omega \\
\hline
\end{tabular}

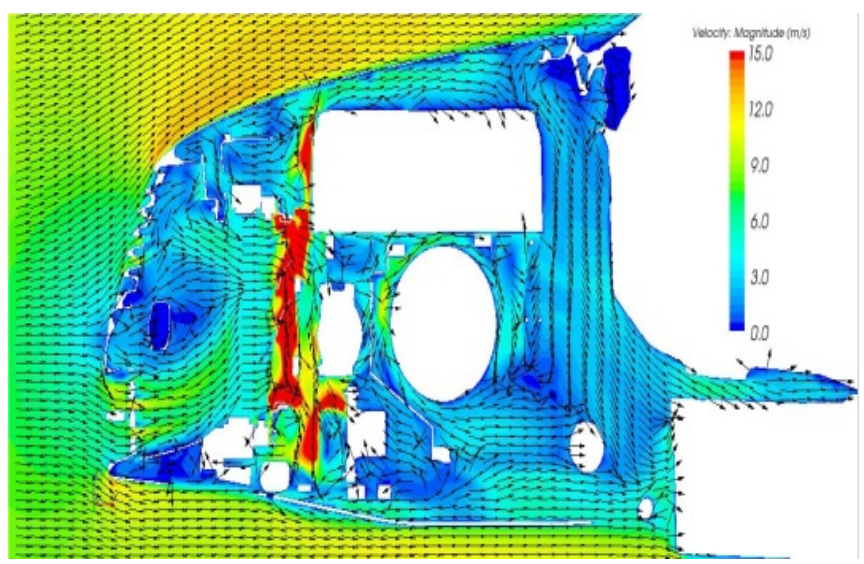

Fig. (2). The cabin CFD result. 
Both the 3D numerical model for cabin thermal management and 1D model for the cooling model are built. Then the velocity matrix can make that the convection heat transfer coefficient and heat transfer obtained from 3D simulation on the flow field and heat transfer characteristics to the radiator.

Where PTU is the radiator of the Electronic controller and FEC is the radiator of the fuel cell.

Table 2. Cooling module input date.

\begin{tabular}{|c|c|}
\hline \multicolumn{2}{|c|}{ Cooling Module Input Date } \\
\hline \hline 1 & Coolant: Water / glycol \\
\hline 2 & The pump curve \\
\hline 3 & Fan characteristic curve \\
\hline 4 & Condenser heat transfer curve \\
\hline 5 & Cooling system pressure \\
\hline 6 & Radiator heat transfer curve \\
\hline 7 & Radiator air resistance curve \\
\hline 8 & Condenser resistance curve \\
\hline 9 & The FEV heat map \\
\hline 10 & The PTU heat map \\
\hline
\end{tabular}

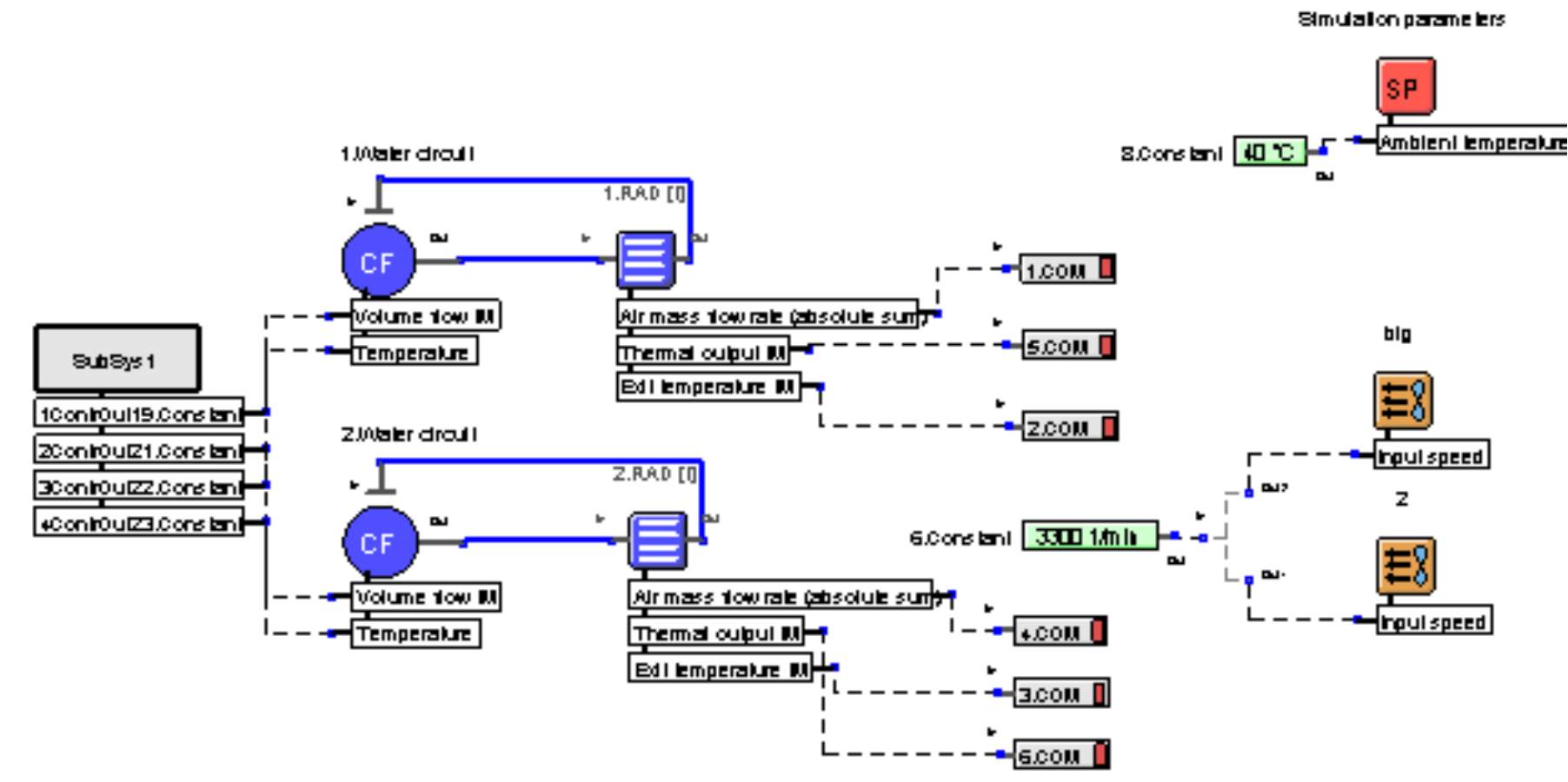

The 1D simulation parameter of cooling module is used is shown in Table 2. It is applied in the test carried out for the vehicle in working condition as shown in Fig. (3). The 1D simulation cooling module input dates are shown in Table 2.

The 1D model of cooling module for air flow model is shown in Fig. (4). It is steady simulation that the temperature is at $30^{\circ} \mathrm{C}$ with the cooling fan running at $3000 \mathrm{rpm}$. The cabin air path model input date for the velocity matrix are shown in Fig. (5). The CFD calculation and the 1D calculation are taken into account for the velocity matrix to accurately calculate the flow and heat transfer model of the fuel cell car.

\section{VERIFICATION}

The simulation results are compared with the test data, as shown in Figs. (6-8); error of $5 \%$, is caused by the very complex flow field in the cabin. There is heat reflux in the part of the cooling module, making the simulation difficult to. The model for cooling system can predict and analyze the performance of the cooling system.

\section{ANALYSIS}

In this paper, the performance of the cooling system is analyzed by a speed of $30 \mathrm{~km} / \mathrm{h}$ of the working vehicle.

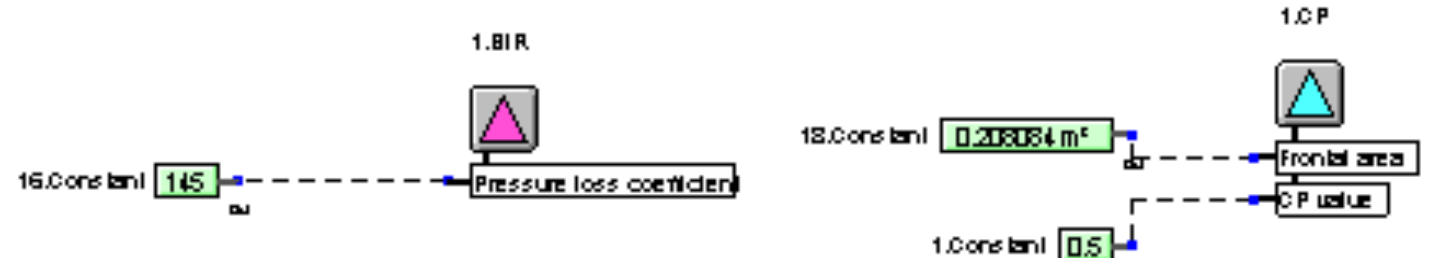

Fig. (3). Cooling module heat transfer model. 
According to Bernoulli's equation of fluid mechanics, when air flows through the grill, cross-section of the grill becomes smaller. With the high-pressure zone near the cabin outside the outside pressure of the cabin becomes higher than the pressure inside. This makes the airflow smoothly into the cabin. Air flows into the cabin through the FCE and PTU radiator, decreasing the velocity of the air due to the air flow through core resistance. But the minimum velocity of air is not at the FCE radiator, because the fan is behind the FCE radiator, therefore the air velocity at the FCE radiator is increased. The air velocity is $1.47 \mathrm{~m} / \mathrm{s}$ at the PTU radiator as shown in Fig. (7).

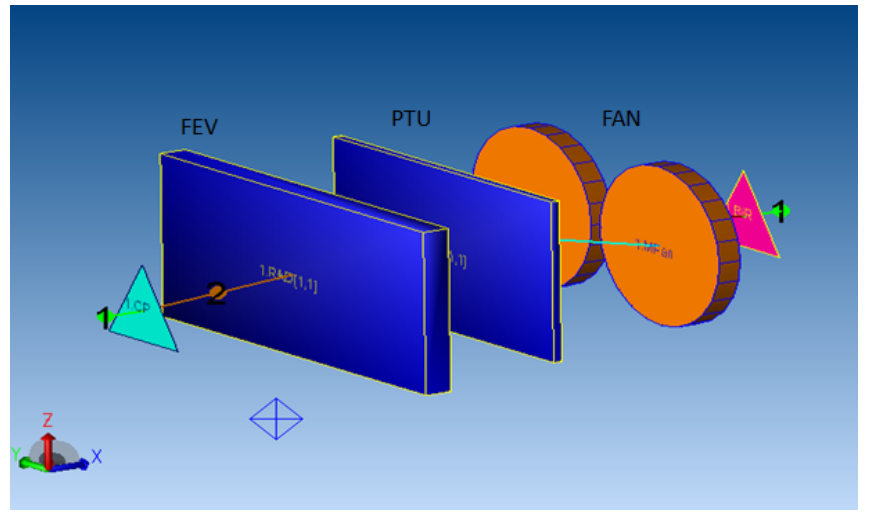

Fig. (4). The velocity matrix.

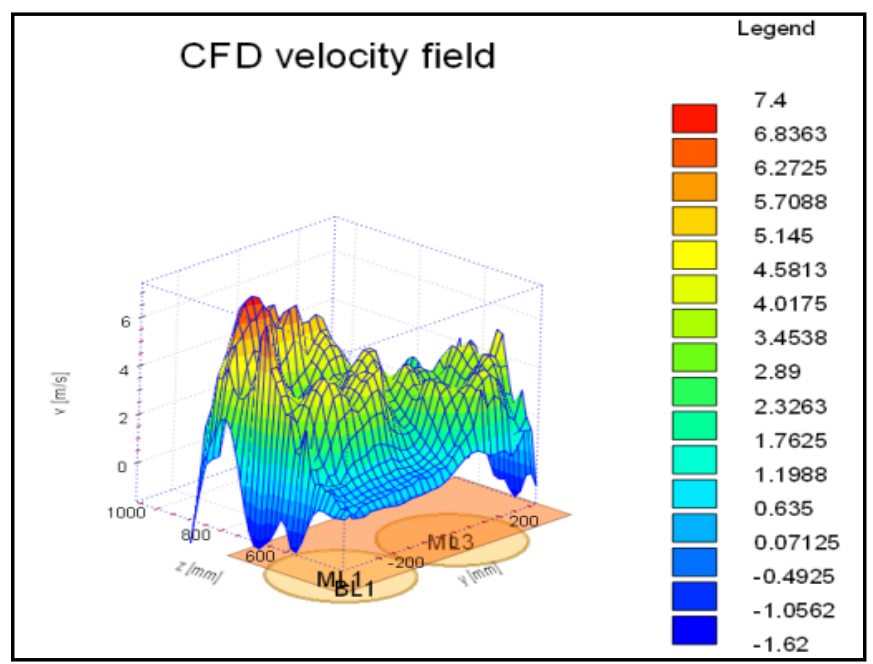

Fig. (5). Air path model of cabin for cooling module.

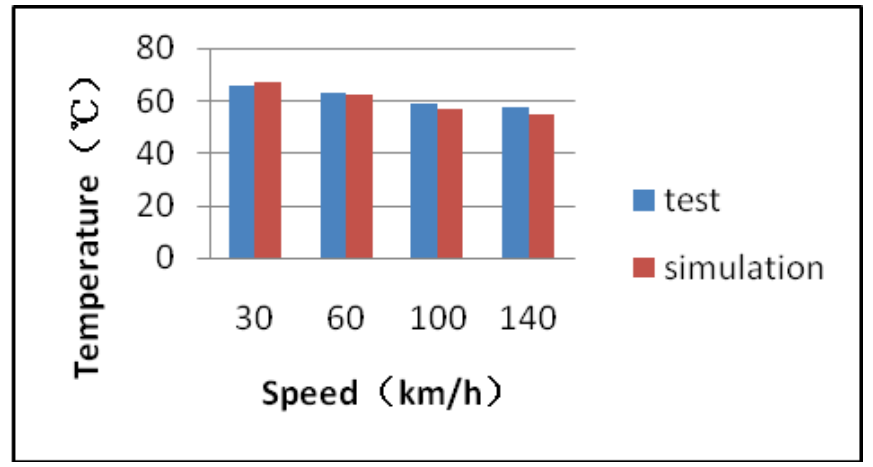

Fig. (6). The coolant of FCE temperature.
Because of the diffusion in the cabin and heat reflux, air flows through the FCE with the temperature of radiator being $46.32^{\circ} \mathrm{C}$ and the temperature of coolant being about $85^{\circ} \mathrm{C}$. The performance of the cooling module is shown in Fig. (10).

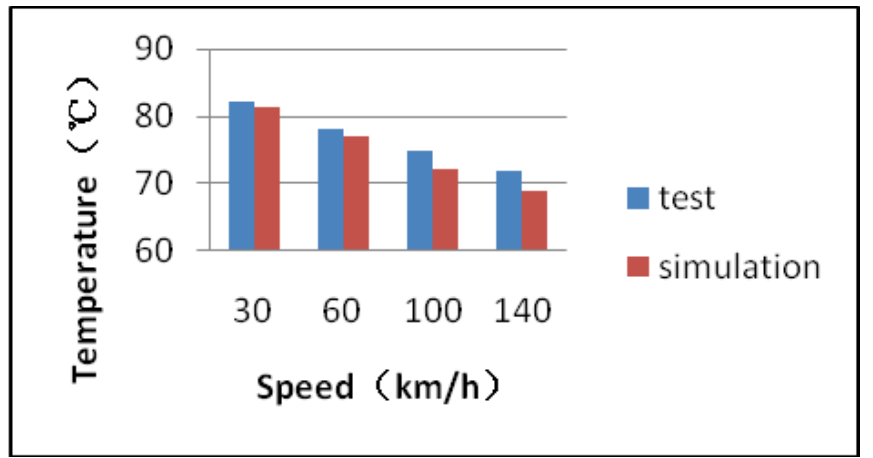

Fig. (7). The coolant of PTU temperature.

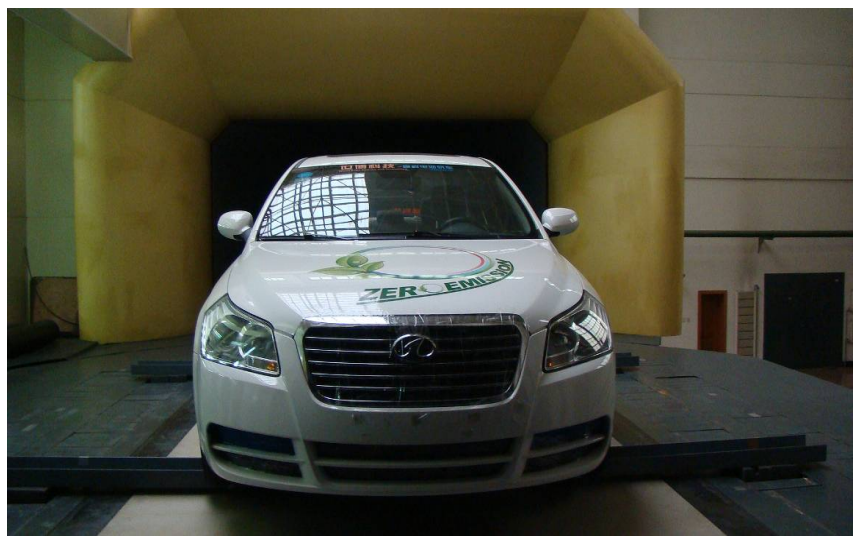

Fig. (8). The fuel cell car test.

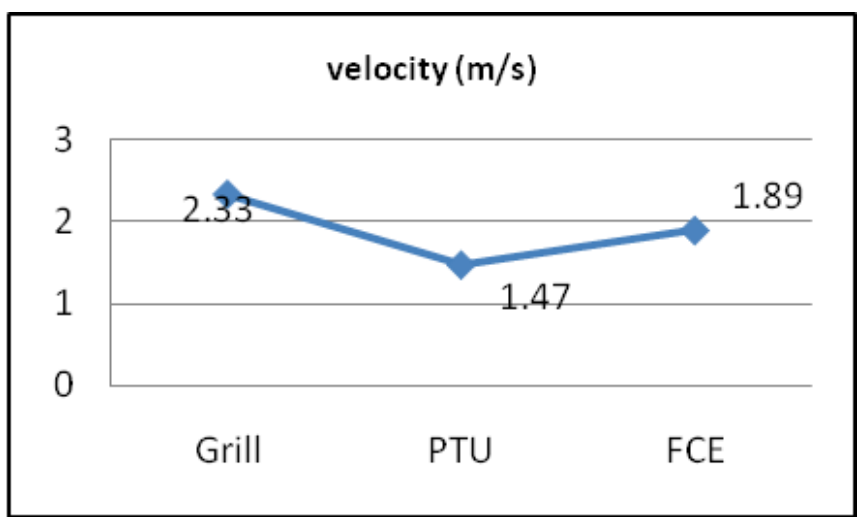

Fig. (9). The air path velocity in different zone.

\section{CONCLUSION}

Simulation cooling module for working of vehicle has been built according to the actual test process of thermal balance test, and the simulation results were compared with the test data to verify the authenticity of the module. This simulation model provides an effective platform for vehicle thermal management analysis. Both 3D numerical model for cabin thermal management and 1D model for the cooling 
model are built. Then the velocity matrix can make that the convection heat transfer coefficient and heat transfer obtained from 3D simulation on the flow field and heat transfer characteristics to the radiator. At last, it can be used in 1D simulation on the cooling system to calculate the temperatures of various components in fuel cell car which will in turn be taken as the boundary conditions of 3D simulation to update the thermal flow characteristics of cooling model for fuel cell car. Such a 3D-1D coupling simulation provides an effective simulation technique for thermal management of fuel cell car.

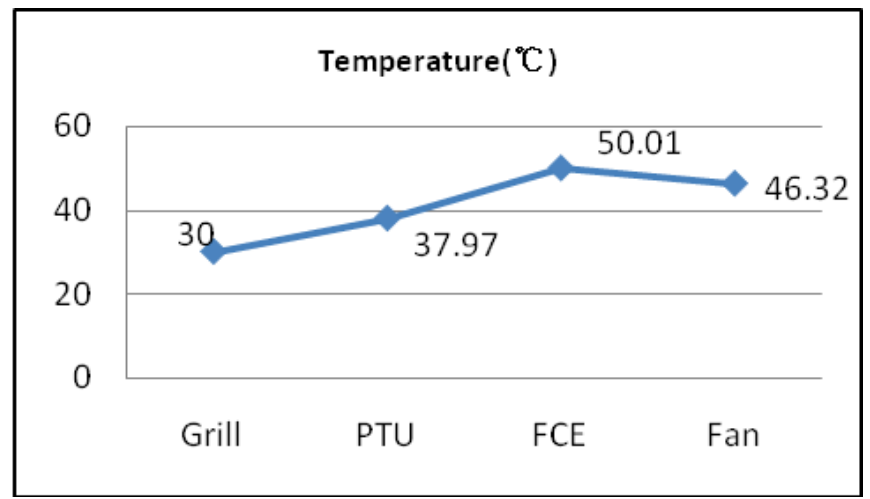

Fig. (10). The air path temperature in different zone.

\section{CONFLICT OF INTEREST}

The author confirms that this article content has no conflict of interest.

\section{ACKNOWLEDGEMENTS}

Declared none.

\section{REFERENCES}

[1] B. L. Yi, "Fuel Cell—Principle, Technology \& Application", Chemical Industry Press, Beijing (2003): 197.

[2] M. Yang, and T. Wenquan. Heat transfer [M]. Version 4. Beijing: Higher Education Press, 2006: 216-217.

[3] J. Fagley, G.U. Wenbin, and Whitehead, L. "Thermal modeling of a PEM fuel cell [C]", Proc 2nd International Conference on fuel Cell Science, Engineering and Technology. New York: ASME, 2004: 141-149.

[4] H. Gary, and B. Ronald, "Measure Vehicle Inertial NHTS Data", November 1998 [C], SAE Paper, 1999-01-1336.

[5] Mizuno Y, and Ishikawa H. Summary of IHRA Pedestrian Safety WG Activities proposed Test Methods to Evaluate Pedestrian Protection.

[6] Afforded by Passenger Cars [C]. The 18th ESVC: North Atlantic Treaty Organization Committee, 2001: 280.

[7] KULI 8.0 User manual, Magna Styer Engineering.

[8] L. Martinez, L. J. Guerra, G. Ferichola, A. Garcia, and T. Yang, Stiffness Corridors for the Current European Fleet [R]. Technical Report APSP31 -0009R, APROSYS, (2006).

[9] J. Larminie, and A. Dicks, "Fuel Cell System Explainer [M]", England: John Wiley \& Sons, Inc, 2003: pp. 22-24.

This is an open access article licensed under the terms of the Creative Commons Attribution Non-Commercial License (http://creativecommons.org/licenses/ by-nc/3.0/) which permits unrestricted, non-commercial use, distribution and reproduction in any medium, provided the work is properly cited. 